\section{Evaluasi Peran Dan Kinerja Konsultan Supervisi Konstruksi Studi Kasus Pekerjaan Penggantian Jembatan Sungai Ata IV Kabupaten Tanah Bumbu}

\section{Bambang Hermanto}

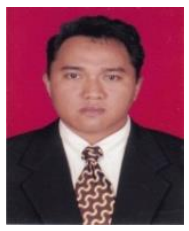

Lahir di Samuda pada 2 Mei 1972 Sarjana (S1) Teknik Sipil Universitas Achmad Yani lulus pada tahun 2005. Sekarang bekerja sebagai Konsultan Supervisi. Dengan pengalaman pada bidang Pengawasan Pembangunan Jalan dan Jembatan.. buletinppi@ulm.ac.id
Pemerintah Pusat maupun Daerah didorong untuk memperbanyak dan meningkatkan fasilitas umum, seperti : pembangunan sarana dan prasarana transportasi, kesehatan, pendidikan serta pemerintahan. Kegiatan ini dilaksanakan pada pembangunan Jembatan Sungai Ata IV yang terdahulu tidak layak fungsi serta banyaknya kerusakan pada struktur bawah dan atas bangunan yang ada sehingga tidak memadai untuk digunakan secara maksimal. Permasalahan yang diangkat dalam makalah ini adalah mengevaluasi kinerja konsultan supervisi konstruksi pada penggantian pembangunan Jembatan Sungai Ata IV Kabupaten Tanah Bumbu. Berdasarkan hasil interview dengan pihak yang bertugas dalam pelaksanaan proyek itu, ternyata segala bentuk kendala, kondisi dan situasi terhadap keterlambatan kerja yang terjadi disana diakibatkan karena kurangnya koordinasi dan komunikasi antar petugas lapangan seperti konsultan pengawas, Dinas Pekerjaan Umum (PU) dan kontraktor sebagai pihak pelaksana pekerjaan pembangunan Jembatan Sungai Ata IV Kabupaten Tanah Bumbu.

\section{Pendahuluan}

Sebubungan dengan meningkatnya jumlah penduduk serta taraf hidup masyarakat sehingga mengharuskan pemerintah pusat maupun daerah untuk memperbanyak dan meningkatkan fasilitas umum, seperti : pembangunan sarana dan prasarana transportasi, kesehatan, pendidikan serta pemerintahan.

Kegiatan ini dilaksanakan karena sarana dan prasarana bangunan konstruksi jembatan Sungai Ata IV yang terdahulu tidak layak pakai untuk dilalui oleh jalur lalu lintas untuk umum dan tidak dapat digunakan secara maksimal, maka dilaksanakanlah Proyek Penggantian Pembangunan Jembatan Sungai Ata IV ini dengan menggunakan dana APBN tahun 2017.

\section{Hasil Kerja}

Evaluasi Peran dan Kinerja Konsultan Supervisi Konstruksi pada pekerjaan pembagunan Jembatan Sungai Ata IV Kab. Tanah Bumbu

Besarnya koefisien korelasi berkisar antara $+1 \mathrm{~s} / \mathrm{d}-1$. Koefisien korelasi menunjukkan kekuatan (strength) hubungan linier danarah hubungan kedua variable acak. Jika koefisien positif, maka kedua variable mempunyai hubungan searah. Sebaliknya, jika koefisien korelasi negatif, maka kedua variabel mempunyai hubungan terbalik. Menurut Sarwono (2008), ada enam (6) criteria untuk memudahkan melakukan interpretasi mengenai kekuatan hubungan antara dua variabel, yaitu :

1.0 : Tidak ada korelasi antara dua varibel
2. $>0-0,25$
: Korelasi sangat lemah
3. $>0,25-0,5$ : Korelasi cukup
4. $>0,5-0,75 \quad$ : Korelasi kuat
5. $>0,75-0,99$ : Korelasi sangat kuat
6. 1
: Korelasi sempurna

Untuk mengetahui seberapa besar korelasi antara jenis proyek yang satu dengan jenis proyek yang lainnya, maka digunakanlah program (SPSS versi 16,0) untuk melakukan korelasi berdasarkan metode spearmanrho. Hasil korelasi antara delapan (8) faktor yang paling berpotensi berpengaruh terhadap kinerja konsultan supervise konstruksi pada proyek Penggantian Jembatan Sungai Ata IV Kabupaten Tanah Bumbu

Dilihat hasil korelasi kinerja-kinerja berdasarkan delapan (8) kinerja yang paling berpengaruh terhadap kinerja konsultan, terdapat delapan (8) korelasi faktor yang mempunyai hubungan yang signifikasi pada level 0,01 yaitu kinerja dalam hal memeriksa / mengevaluasi jadwal pelaksanaan pekerjaan struktur yang telah dibuat oleh kontraktor, menjamin terlaksananya segala syarat dari KAK yang berkaitan dengan organisasi dan pelaksanaan pekerjaan selesai dengan baik sehingga memuaskan pemberi tugas, mengadakan hubungan eksternal yang berkaitan dengan kepentingan dan keperluan pekerjaan 
pengawasan konstruksi, melakukan penolakan apabila dalam pelaksanaan pekerjaan terjadi penyimpangan dari desain struktur yang ada, evaluasi dan pemeriksaan hasil perencanaan yang berkaitan dengan penyusunan rencana anggaran biaya pekerjaan, bertanggung jawab atas hubungan kerja antar pihak terkait proyek, dan melakukan analisa pemilihan kebijakan teknologi konstruksi bangunan yang akan diterapkan. Yang berkaitan dengan rekayasa konstruksi

\begin{tabular}{|l|l|r|r|}
\hline & & Pengguna Jasa & Penyedia Jasa \\
\hline \multirow{4}{*}{ Pengguna Jasa } & Pearson Correlation & 1 & $-.562 *$ \\
\cline { 2 - 4 } & Sig. (2-tailed) & & .010 \\
\cline { 2 - 4 } & $\mathrm{N}$ & 20 & 20 \\
\hline Penyedia Jasa & Pearson Correlation & $-.562 *$ & 1 \\
\cline { 2 - 4 } & Sig. (2-tailed) & .010 & \\
\cline { 2 - 4 } & $\mathrm{N}$ & 20 & 20 \\
\hline
\end{tabular}

**. Correlation is significant at the 0.01 level (2-tailed).

Tabel 1.1. Tabel Korelasi Spearman's Rank Berdasarkan Kategor Pendidikan Terakhir

\begin{tabular}{|c|l|r|r}
\hline & & Non Sarjana & Sarjan \\
\hline \multirow{4}{*}{ Non Sarjana } & Pearson Correlation & 1 & -.91 \\
& Sig. (2-tailed) & & \\
\cline { 2 - 4 } & N & 20 & \\
\hline \multirow{5}{*}{ Sarjana } & Pearson Correlation & $-.913^{-*}$ & \\
\cline { 2 - 4 } & Sig. (2-tailed) & .000 & \\
\cline { 2 - 5 } & N & 20 & \\
\hline
\end{tabular}

${ }^{\star \star}$. Correlation is significant at the 0.01 level (2-tailed)

Tabel 1.2. Tabel Korelasi Spearman's Rank Berdasarkan Kategori Lama Pengalaman Kerja

\begin{tabular}{|l|l|r|r|}
\hline & & 1-5 Tahun & $>5$ Tá \\
\hline \multirow{3}{*}{ 1-5 Tahun } & Pearson Correlation & 1 & - \\
\cline { 2 - 4 } & Sig. (2-tailed) & 20 & \\
\cline { 2 - 4 } & N & $-.851^{-\mu}$ & \\
\hline \multirow{2}{*}{$>5$ Tahun } & Pearson Correlation & .000 & \\
\cline { 2 - 5 } & Sig. (2-tailed) & 20 & \\
\cline { 2 - 5 } & N & & \\
\hline
\end{tabular}

**. Correlation is significant at the 0.01 level (2-tailed)

Tabel 1.3 Korelasi Spearman's Rank Berdasarkan Kategori Status Responden di proyek

\begin{tabular}{|l|l|r|r|}
\hline & & Pengguna Jasa & Penyedia Jasa \\
\hline \multirow{5}{*}{ Pengguna Jasa } & Pearson Correlation & 1 & -.562 \\
\cline { 2 - 4 } & Sig. (2-tailed) & & .010 \\
\cline { 2 - 4 } & Nenyedia Jasa & 20 & 20 \\
& Pearson Correlation & -.562 & 1 \\
& Sig. (2-tailed) & .010 & \\
\cline { 2 - 4 } & $\mathrm{N}$ & 20 & 20 \\
\hline
\end{tabular}

**. Correlation is significant at the 0.01 level (2-tailed)
Dari hasil korelasi pada tabel 1.1, 1.2 dan 1.3, terlihat bahwa korelasi peringkat dari kinerja-kinerja konsultan supervise konstruksi pada proyek-proyek konstruksi berdasarkan kategori pendidikan terakhir, lama pengalaman kerja serta status responden di proyek, masing-masing memiliki korelasi yang kuat atau signifikan pada level 0,01. Hal ini menunjukkan bahwa hasil peringkat dari kinerja-kinerja penelitian ini sudah mewakili untuk semua kategori yang telah disusun sebelumnya.

\section{Kesimpulan}

A. Berdasarkan hasil penelitian yang telah dilakukan mengenai identifikasi peranan konsultan supervisi konstruksi pada Proyek Penggantian Jembatan Sungai Ata IV di Kabupaten Tanah Bumbu. Maka peranan konsultan supervisi konstruksi adalah :

1. Mengadakan hubungan eksternal yang berkaitan dengan kepentingan dan keperluan pekerjaan pengawasan konstruksi.

2. Menjamin terlaksananya segala syarat dari KAK yang berkaitan dengan organisasi dan pelaksanaan pekerjaan selesai dengan baik sehingga memuaskan pemberi tugas.

3. Memeriksa / mengevaluasi jadwal pelaksanaan pekerjaan struktur yang telah dibuat oleh kontraktor.

4. Mengatur pelaksanaan kegiatan pekerjaan agar berjalan secara lancar.

5. Melakukan penolakan apabila dalam pelaksanaan pekerjaan terjadi penyimpangan dari desain struktur yang ada.

6. Evaluasi dan pemeriksaan hasil rencana anggaran biaya pekerjaan.

7. Bertanggung jawab atas hubungan kerja antar pihak terkait proyek.

8. Melakukan analisa pemilihan kebijakan teknologi konstruksi bangunan yang akan diterapkan berkaitan dengan rekayasa konstruksi.

\section{Ucapan Terima kasih}

Segala puji dan syukur saya panjatkan kehadirat Allah SWT, shalawat dan salam atas junjungan Nabi kita Muhammad SAW, karena atas petunjukNya sehingga tugas karya tulis ini dapat diselesaikan. Pada kesempatan ini pula saya ucapkan terima kasih kepada : Prof. Dr. Ir. Rusdi HA, M.Sc, IPU, selaku Kaprodi PSPPI ULM; Dr. Ir. Abdul Ghofur, ST., MT., IPM, selaku Sekprodi PSPPI ULM; Ir. Chairul Irawan, ST., MT., Ph.D, IPM, selaku Pembimbing Perwalian PSPPI ULM, yang telah memberikan masukan dan pengarahan dalam penyelesaian Tugas Karya Tulis ini; Dosen PSPPI ULM yang telah memberikan bimbingan IImu Pengetahuan dalam karya tulis ini; Pejabat Pembuat Komitmen (PPK04) PUPR Wilayah I Provinsi Kalsel; Konsultan PT. Global 
Profex Synergy; Kontraktor PT. Karya Mitra Jaya Perkasa; serta semua Pihak yang telah membantu hingga tugas Karya Tulis ini selesai.

\section{Referensi}

1 A.D, Austen dan R.H. Neale. 1991. "Manajemen Proyek Konstruksi", Jakarta : PPM.

2 Direktorat Jendral Cipta Karya, DPU "Tugas dan Tanggung Jawab Konsultan Manajemen

3 Konstruksi", Modul V Buku 3, Jakarta Selatan 1993.

4 Direktorat Jendral CiptaKarya, DPU “ Kerangka Acuan Kerja (KAK) Pengawasan Bangunan Gedung Negara " Jakarta, 1997.

5 Halim, Abdul dkk. 2003. "Sistem Pengendalian Manajemen Edisi Revisi". Yogyakarta : UPPAMP YKPN.

6 Jonathan, Sarwono, 2008. "Metode Penelitian Kuantitatif dan Kualitatif". Yogyakarta: Graha ilmu

7 Sekolah Menengah Kejuruan, 1999. "Pengendalian Dan Pengawasan Pelaksanaan Pekerjaan", Penerbit Departemen Pendidikan Dan Kebudayaan Direktorat Pendidikan Menengah Kejuruan, Jakarta Selatan.

8 Sugiyono, 2008. "Metode Penelitian Bisnis". Cetakan Kesebelas. Bandung : CV. Alfabeta.

9 Tarore, Huibert, dan Mendagri, Robert J.M., 2006. Sistem Manajemen Proyek Konstruksi.

10 (SIMPROKON), Tim Penerbit Jurusan Teknik Sipil Fakultas Teknik Universitas Sam Ratulangi Manado.

11 Uma, Sekaran, 2006, "Metodologi Penelitian Untuk Bisnis", Edisi 4, Buku 1, Jakarta : Salemba Empat. 